\title{
Kinesiographic study of complete denture movement related to mucosa displacement in edentulous patients
}

\section{Estudo cinesiográfico da movimentação da prótese total resultante da deformação da fibromucosa em desdentados totais}

Marco Antonio Compagnoni*

Raphael Freitas de Souza**

Cláudio Rodrigues Leles***

\begin{abstract}
The mucosa that covers the residual ridges of edentulous patients may present some distortion or displacement when occlusal loading is applied in complete dentures. This distortion and movement of the denture can result in acceleration of residual ridge resorption and loss of retention and stability. The aim of this study was to analyze the pattern of upper complete denture movement related to underlying mucosa displacement. A sample of 10 complete denture wearers was randomly selected, which had acceptable upper and lower dentures and normal volume and resilience of residual ridges. The kinesiographic instrument K6-I Diagnostic System ${ }^{\mathbb{B}}$ was used to measure denture movements, according to the method proposed by Maeda et al. ${ }^{7}, 1984$. Denture movements were measured under the following experimental conditions: (A) 3 maximum voluntary clenching cycles and (B) unilateral chewing for 20 seconds. The results showed that under physiological load, oral mucosa distortion has two distinct phases: a fast initial displacement as load is applied and a slower and incomplete recovery when load is removed. Intermittent loading such as chewing progressively reduces the magnitude of the denture displacement and the recovery of the mucosa is gradually more incomplete.
\end{abstract}

DESCRIPTORS: Mouth mucosa; Denture, complete.

RESUMO: Devido às características de compressibilidade da fibromucosa, a incidência de cargas sobre a prótese total resulta na movimentação da prótese em direção ao rebordo, a qual pode resultar no aumento da reabsorção do rebordo residual, na desadaptação interna e na perda de retenção da prótese. O objetivo do presente estudo é avaliar o padrão de movimentação da prótese total superior em função da deformação da fibromucosa. Foram selecionados 10 pacientes usuários de próteses totais bimaxilares, com retenção satisfatória e relações oclusais corretas e rebordos alveolares com volume e grau de resiliência normais. Para a análise da movimentação da prótese total superior foi utilizado o sistema eletrônico K6-I Diagnostic System ${ }^{\circledR}$, sendo o dispositivo eletromagnético fixado na região vestibular dos incisivos centrais da prótese superior, de acordo com uma adaptação do método sugerido por Maeda et al. ${ }^{7}$ (1984). Foram obtidos registros gráficos em duas condições experimentais: (A) 3 ciclos de apertamento máximo voluntário e (B) mastigação unilateral simulada por um período de 20 segundos. Os resultados mostraram um padrão uniforme de movimentação durante o apertamento máximo e a mastigação simulada. Sob a ação de cargas, a fibromucosa apresenta uma deformação rápida e uma recuperação mais lenta e incompleta, de forma que a ação repetida da aplicação de carga reduz gradualmente a quantidade de movimentação e retorno da prótese; na mastigação simulada não há a completa recuperação da fibromucosa durante os ciclos mastigatórios.

DESCRITORES: Mucosa bucal; Prótese total.

\section{INTRODUCTION}

When occlusal pressure is applied to a complete denture, there is a displacement or distortion of the mucous membrane and a consequent movement of the denture. This displacement is related to changes in blood circulation and tissue elements of connective tissues ${ }^{5,8}$, and depends on the histological and morphological characteristics of the mucous membrane that is in close contact with the prosthesis.

Kydd et al. ${ }^{5}$ observed that sustained loading can compress the tissues up to $45 \%$ of its original thickness. This deformation is viscoelastic in nature, which means that its mechanical response depends on the rate of loading, its magnitude, duration and previous loading history ${ }^{10}$.

\footnotetext{
*Chairman Professor; **Graduate Student - Department of Dental Materials and Prosthodontics, Araraquara Dental School, São

Paulo State University.

***Professor, Department of Prevention and Oral Rehabilitation, School of Dentistry, Federal University of Goiás.
} 
Compagnoni MA, Souza RF, Leles CR. Kinesiographic study of complete denture movement related to mucosa displacement in edentulous patients. Pesqui Odontol Bras 2003;17(4):356-61.

The distortion of the masticatory mucosa and the related movement of the denture can result in acceleration of residual ridge resorption and loss of retention and stability of the denture. Chong ${ }^{2}$ observed a close relation between internal adaptation and movement of the maxillary denture during masticatory function. Well-fitted dentures exhibited a lesser amount of movement than did poorly fitted ones. The range of well-fitted dentures movement varied from 0 to $1.4 \mathrm{~mm}$ on the chewing side and from 0.1 to 1.6 on the other side.

The thickness and displaceability of the mucosal support for dentures should be considered when recording impressions. Mobile tissue presents problems of support and stability which are dealt with either by surgical reduction in the thickness of these tissues or by using special impression techniques which distribute the load in a particular manner.

Clinical assessment of the supporting tissue in complete denture patients is important for preoperative diagnosis and treatment planning. Such clinical assessment tends to differ considerably between dentists and most assessment is subjective $^{9}$. Therefore, it is important to make clinical mucosal displacement reliable and accurate. The aim of the present study was to observe the behavior of complete denture displacement and tissual deformation under occlusal loading in different clinical situations. The viability of a kinesiographic instrument to measure this displacement was also analysed.

\section{MATERIAL AND METHOD}

Ten complete denture wearers were selected according to the following criteria: (1) recently installed upper and lower conventional complete dentures, (2) good retention and satisfactory internal adaptation of the dentures, (3) normal volume and resilience of residual ridges, and (4) informed consent of the patients. Their ages ranged from 52 to 77 years, six were female and four male. Furthermore, the initial project was approved by the Ethical Committee, Araraquara Dental School. All participants were informed on the nature of the investigation and agreed to take part in it.

A kinesiographic instrument (K6-I Diagnostic System, Myotronics Research Inc., Seattle, WA, USA) connected to a personal computer system (Microsoft Windows 95, Version 4.1, Microsoft Corporation, Redmond, WA, USA), was used for patient evaluation and graphic recordings.

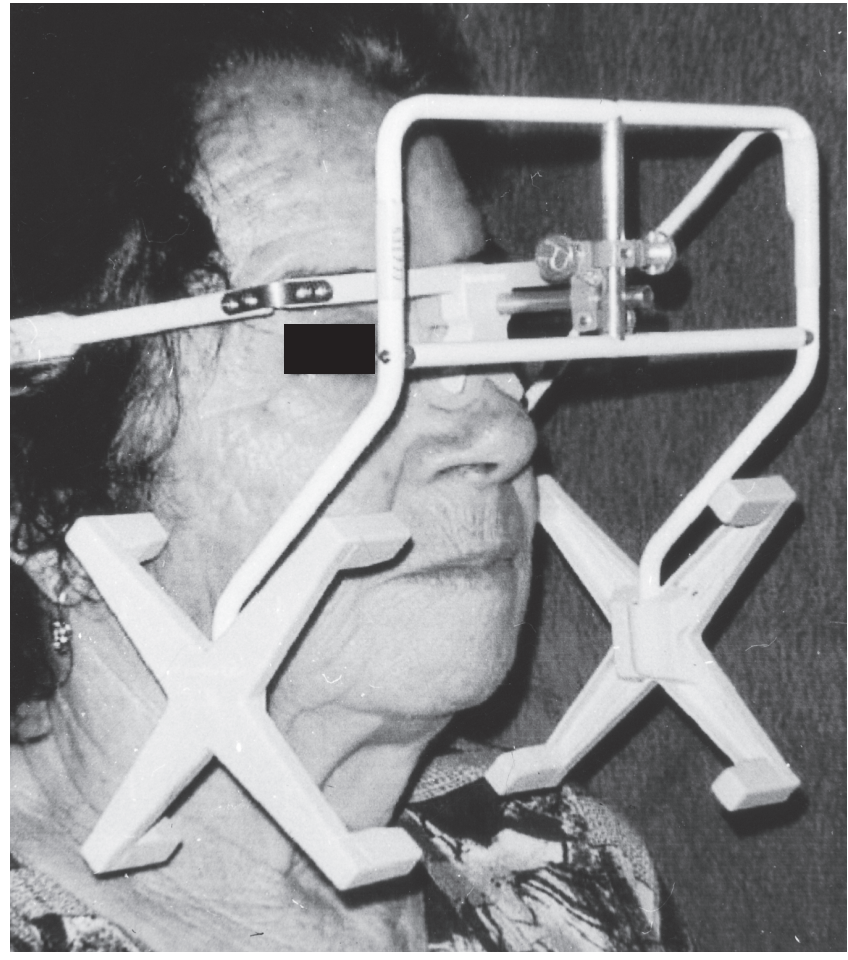

FIGURE 1 - Sensory assay in position.

Patients were erectly seated, with the Frankfurt plane parallel with the horizontal plane. The sensory array was positioned according to the manufacturer's instructions (Figure 1) and the magnet was attached to the labial midline surface of the maxillary complete denture, as proposed by Maeda et al. ${ }^{7}$.

Linear vertical movements of the maxillary denture were registered under the following experimental conditions:

1. Maximum voluntary clenching (MVC) - 3 cycles of three-seconds MVC and a rest period of five-seconds between each cycle.

2. Simulated mastication (SM) - unilateral chewing (preferred side) of a test food for a $20 \mathrm{sec}-$ onds period of time. The material used as a food substitute was a $10 \times 10 \times 5 \mathrm{~mm}$ polysulfide specimen (Regular Permlastic', Kerr Corporation, Orange, CA, USA). The material had a soft rubber consistency and was maintained throughout the chewing cycle.

The sets of measurements were transferred to an image editor software (PhotoImpact SE, Version 3.02 (1997), Unlead Systems Inc., Taipei, Taiwan) for further assessment. The measurement scale was converted from pixels to millimeters by selecting reference points on $\mathrm{x}$ and $\mathrm{y}$ axis and com- 
Compagnoni MA, Souza RF, Leles CR. Kinesiographic study of complete denture movement related to mucosa displacement in edentulous patients. Pesqui Odontol Bras 2003;17(4):356-61.

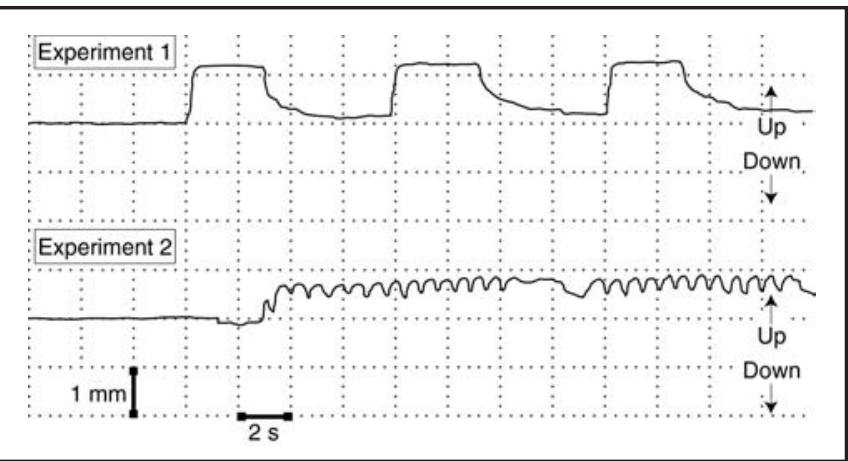

GRAPH 1 - Example of graphic registration of both experimental conditions (maximum voluntary clenching and simulated chewing cycles).

paring them to the millimeter scale of the kinesiographic tracings. Assuming that tracings presented the same magnification, a conversion scale was established by using the following formula:

$a=0.0435 . b$

Where:

a- distance between two selected points (in millimeters).

b- number of pixels

Descriptive statistics and correlation analysis were performed at a 95\% level of confidence.

\section{RESULTS AND DISCUSSION}

Graph 1 illustrates a common graphic pattern of all subjects in both experimental conditions. The displacement/time ratio selected was $1 \mathrm{~mm} / 2 \mathrm{~s}$, expressed in the vertical and horizontal axes, respectively. According to this graphic pattern, the following assumptions could be made:

\section{Experiment 1}

Immediately after denture clenching an instantaneous and fast upper displacement of the denture occurred. As long as the clenching force was sustained for 3 seconds, the altered position of the denture was maintained constant. Subsequently, when the clenching force was interrupted, there was a gradual recovery of denture initial position. During this recovery, two distinct phases were clearly recognized: an initial fast recovery and a late delayed and gradual recovery that did not complete until the next clenching cycle. This typical behavior is illustrated in Graph 2 .

These findings were similar to the observations in dogs reported by Wills, Manderson ${ }^{10}$ (1977). Mucosa behavior under abrupt loading showed an immediate elastic displacement. If this loading is maintained there is a tendency to a subsequent

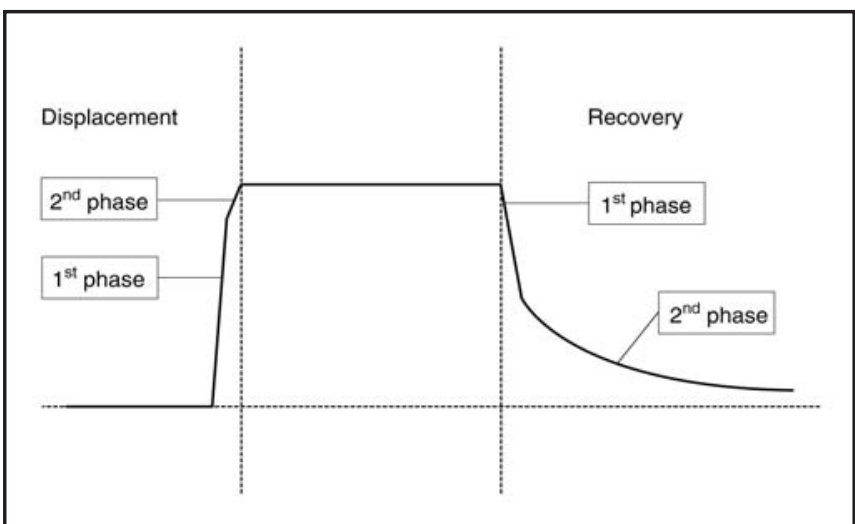

GRAPH 2 - Theoretical model of vertical denture movement during maximum voluntary clenching.

gradual displacement. When load is removed, an instantaneous recovery takes place (elastic recovery), followed by a slow constant recovery (viscoelastic recovery) that can last up to three hours until its initial condition, as long as blood and extracellular fluids are expelled in a slow and steady way. In another animal study, Picton, Wills ${ }^{8}$ (1978) also observed these viscoelastic properties of the mucosa under tissue-supported prosthetic baseplates.

In the present study, the measurements of the graphic registrations varied widely and are described in Tables 1 and 2 . The respective means are shown in Graphs 3 and 4.

These values are comparable to those of previous studies ${ }^{8,10}$. The overall amount of denture displacement $(0.82 \mathrm{~mm})$ was greater than its related recovery $(0.75 \mathrm{~mm})$. Moreover, as stated by Picton, Wills $^{8}$ (1978), if the cycles of loading are repeated in a less than 1.5 minutes time interval, mucosa recovery tends to be progressively more incomplete. This occurrence is clearly verified when comparing the decreasing quantity of displacement and recovery between the three clenching cycles.

The level of displacement and recovery varied widely between patients. The possible explanation is related to anatomical and physiological characteristics of the mucosa that influence denture support, prosthetic features like denture extension, internal adaptation, occlusal relations, and forces produced by occlusion ${ }^{1,3}$. Ismail ${ }^{4}$ (1971) reported a vertical displacement of dentures that ranged from $0.5 \mathrm{~mm}$ to $2.5 \mathrm{~mm}$ (mean $=0.94 \mathrm{~mm})$. Maeda et al. ${ }^{7}$ (1984), using a kinesiographic instrument in two patients observed a vertical displacement from $0.5 \mathrm{~mm}$ to $1.6 \mathrm{~mm}$ resultant from maximal clenching sustained for 2 seconds. 
Compagnoni MA, Souza RF, Leles CR. Kinesiographic study of complete denture movement related to mucosa displacement in edentulous patients. Pesqui Odontol Bras 2003;17(4):356-61.

TABLE 1 - Vertical denture movement during maximum voluntary clenching (in millimeters).

\begin{tabular}{c|c|c|c|c}
\hline \hline Patient & $1^{\text {st }}$ cycle & $2^{\text {nd }}$ cycle & $3^{\text {rd }}$ cycle & Mean \\
\hline 1 & 0.522 & 0.435 & 0.435 & 0.464 \\
\hline 2 & 0.435 & 0.435 & 0.435 & 0.435 \\
\hline 3 & 1.478 & 1.304 & 1.174 & 1.319 \\
\hline 4 & 0.435 & 0.348 & 0.304 & 0.362 \\
\hline 5 & 0.957 & 0.870 & 0.870 & 0.899 \\
\hline 6 & 0.870 & 0.596 & 0.696 & 0.720 \\
\hline 7 & 1.130 & 0.957 & 0.870 & 0.986 \\
\hline 8 & 1.435 & 1.261 & 1.261 & 1.319 \\
\hline 9 & 0.609 & 0.609 & 0.565 & 0.594 \\
\hline 10 & 1.174 & 1.087 & 1.043 & 1.101 \\
\hline \hline
\end{tabular}

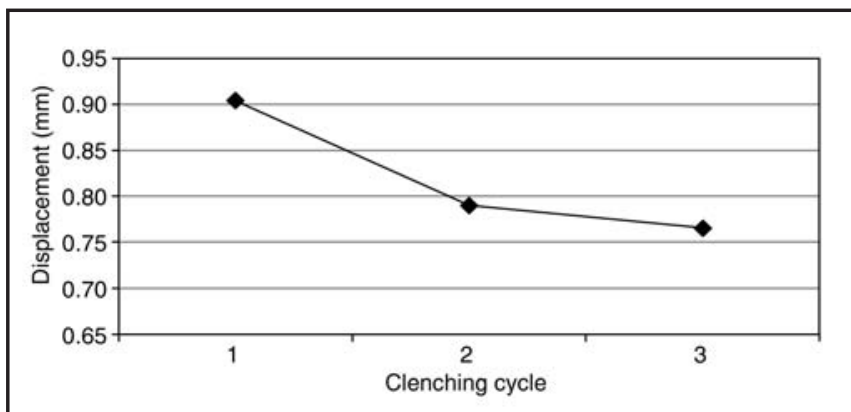

GRAPH 3 - Mean vertical denture displacement according to the clenching cycle.

The rapid phase of the displacement represents the greatest part of the total displacement and the slower part of denture recovery corresponds to the greatest part of overall recovery (Graph 5 ). This peculiarity is due to marked differences in velocity of diffusion and return of blood and extracellular fluids. During maximal clenching this effect is more apparent because the magnitude of loading is directly proportional to the extent of compression of cellular bodies around tissue ${ }^{10}$.

The variation in the displacement and recovery times with the loading cycles can be explained on the basis of fluid flow of the tissues within the palatal mucosa, which is determined by the pressure pattern under the denture baseplate.

The recovery of the mucosa is also prolonged and of variable duration ${ }^{6}$. This would indicate that there is not a simple recovery mechanism when load is removed. The most likely explanation is that fluid (blood and extra-cellular fluid) is expelled from loaded areas and the recovery is con-
TABLE 2 - Recovery movement of the upper complete denture after maximum voluntary clenching (in millimeters).

\begin{tabular}{c|c|c|c|c}
\hline \hline Patient & $1^{\text {st }}$ cycle & $2^{\text {nd }}$ cycle & $3^{\text {rd }}$ cycle & Mean \\
\hline 1 & 0.435 & 0.391 & 0.478 & 0.435 \\
\hline 2 & 0.348 & 0.435 & 0.478 & 0.420 \\
\hline 3 & 1.261 & 1.174 & 1.130 & 1.188 \\
\hline 4 & 0.348 & 0.348 & 0.261 & 0.319 \\
\hline 5 & 0.957 & 0.913 & 0.913 & 0.928 \\
\hline 6 & 0.696 & 0.696 & 0.652 & 0.681 \\
\hline 7 & 0.913 & 0.826 & 0.826 & 0.855 \\
\hline 8 & 1.130 & 1.130 & 0.957 & 1.072 \\
\hline 9 & 0.478 & 0.522 & 0.652 & 0.551 \\
\hline 10 & 1.043 & 1.000 & 1.043 & 1.029 \\
\hline Mean & 0.761 & 0.743 & 0.739 & 0.748 \\
\hline \hline
\end{tabular}

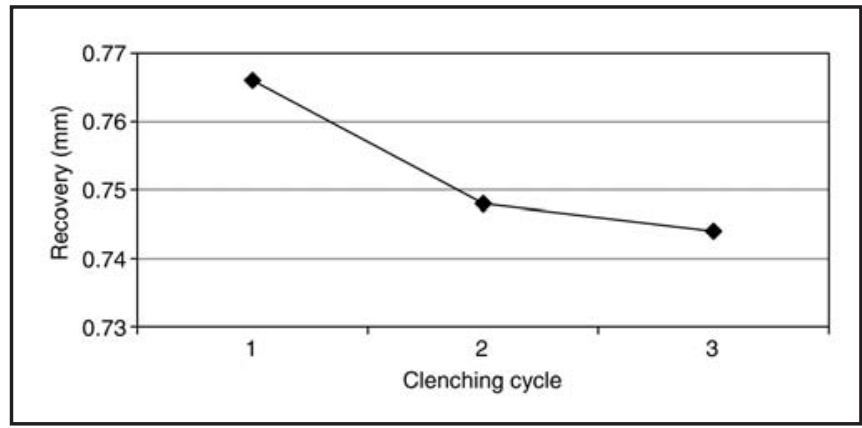

GRAPH 4 - Mean vertical denture recovery according to the clenching cycle.

trolled by the rate at which these fluids return to the loaded area $^{10}$.

\section{Experiment 2}

Reproducible graphs of vertical movement of upper denture during simulated chewing was obtained in 6 of the 10 selected patients. A common pattern was observed in all patients and this model is schematically illustrated in Graph 1 . Since there is not enough time between two chewing cycles, a residual displacement is maintained throughout the masticatory activity. Consequently, there is an incomplete recovery of compression of the mucosa. The values of vertical displacement and residual displacement are described in Table 3. A positive correlation was observed between number of chewing cycles and amount of residual displacement. As the number of chewing cycles increase, a significant increasing in mucosa residual displacement is observed $(r=0.68 ; \mathrm{p}<0.01)$, as shown in Graph 6. 
Compagnoni MA, Souza RF, Leles CR. Kinesiographic study of complete denture movement related to mucosa displacement in edentulous patients. Pesqui Odontol Bras 2003;17(4):356-61.

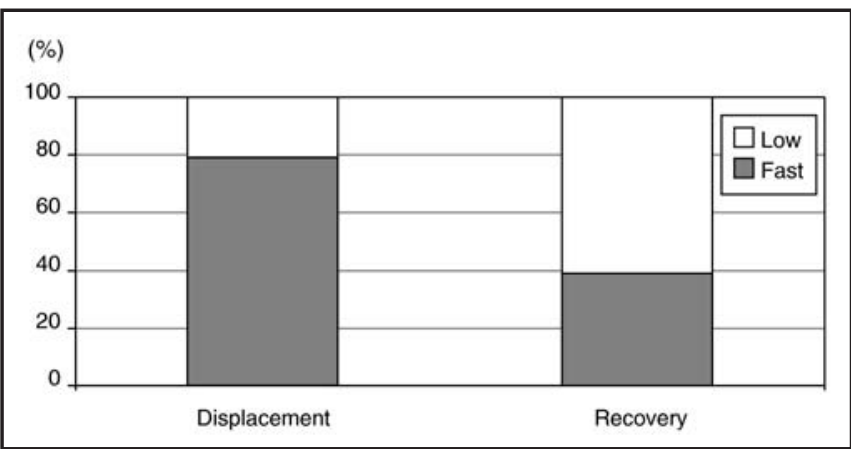

GRAPH 5 - Comparison between faster and slower phases during displacement and recovery of denture.

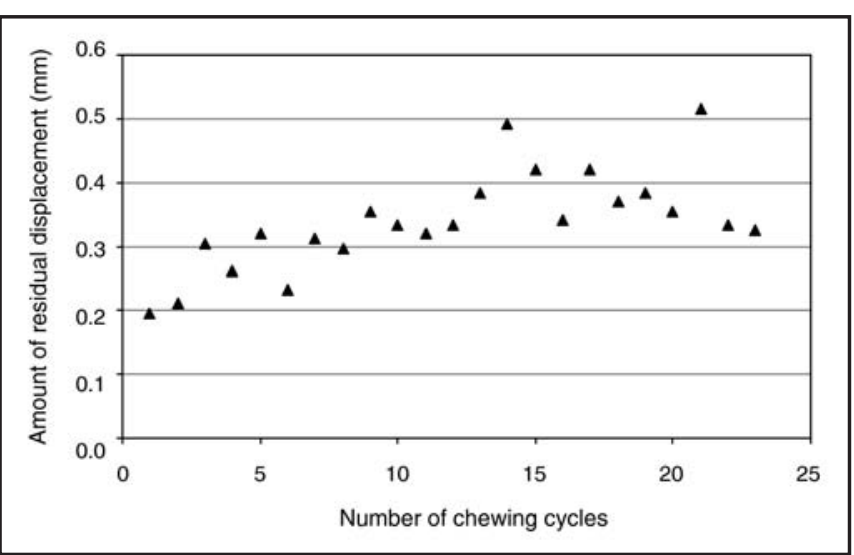

GRAPH 6 - Mean residual displacement of denture as a function of the number of chewing cycles.

Picton, Wills ${ }^{8}$ (1978) also reported that chewing activity causes a progressive intrusion of the denture base, although this effect tends to become stable within 20 or 30 chewing cycles. This intrusion can last up to 10 minutes until its complete recovery ${ }^{8}$.

The kinesiographic method was employed in previous studies to evaluate viscoelastic properties of the mucosa ${ }^{2,7}$, and was considered to be useful for documentation of denture displacement under different conditions of occlusal loading.

As denture displacement related to supporting tissues distortion could disturb denture balance, clinical variables related to the displaceability of the mucosa should be properly assessed by dentists, even though objective assessment at chairside is extremely difficult ${ }^{9}$.
TABLE 3 - Values of vertical denture movement and residual displacement during simulated chewing.

\begin{tabular}{|c|c|c|c|c|}
\hline \multirow{2}{*}{ Patient } & \multirow{2}{*}{$\begin{array}{l}\text { Number of } \\
\text { chewing } \\
\text { cycles }\end{array}$} & \multirow{2}{*}{$\begin{array}{c}\text { Maximal } \\
\text { vertical } \\
\text { displacement } \\
\text { of denture }\end{array}$} & \multicolumn{2}{|c|}{$\begin{array}{c}\text { Residual } \\
\text { displacement }(\mathrm{mm})\end{array}$} \\
\hline & & & Mean & $\mathrm{SD}$ \\
\hline 1 & 27 & 0.9 & 0.504 & 0.10 \\
\hline 2 & 27 & 0.7 & 0.192 & 0.05 \\
\hline 3 & 28 & 1.5 & 0.637 & 0.13 \\
\hline 5 & 39 & 1.4 & 0.234 & 0.35 \\
\hline 8 & 25 & 1.5 & 0.553 & 0.24 \\
\hline 10 & 23 & 1.7 & 0.081 & 0.23 \\
\hline Mean & 28 & 1.28 & 0.367 & 0.18 \\
\hline
\end{tabular}

These results can also be applied to implant-supported overdentures or removable partial dentures that have mucosa-borne support. The considerably higher fluid component of mucosa can lead to increased horizontal loading under implants or teeth and clinical management may include impression procedures that consider tissue resiliency and displaceability.

\section{CONCLUSION}

Under the present experimental conditions there was a consistent movement of the upper denture as a result of mucosa displacement during maximum voluntary clenching and simulated chewing, and the following conclusions could be drawn:

- Under occlusal loading, the mucosa revealed a fast and immediate displacement and a gradual and incomplete recovery.

- Repeated loading cycles gradually reduced the amount of displacement and recovery of the mucosa.

- During simulated chewing cycles there was not a complete recovery of the mucosa between each chewing stroke.

\section{ACKNOWLEDGEMENTS}

This study was supported by Fundação de Amparo à Pesquisa do Estado de São Paulo (FAPESP) - Grant \#99/11727-0. 
Compagnoni MA, Souza RF, Leles CR. Kinesiographic study of complete denture movement related to mucosa displacement in edentulous patients. Pesqui Odontol Bras 2003;17(4):356-61.

\section{REFERENCES}

1. Bearn E. Effect of different occlusal profiles on the masticatory forces transmitted by complete dentures. Br Dent J $1973 ; 134: 7-10$

2. Chong LC. Movement of maxillary complete dentures - a kinesiographic study. J Dent 1983;11:257-63.

3. Cutright D, Brudvik JS, Gay WD, Selting WJ. Tissue pressure under complete maxillary dentures. J Prosthet Dent 1976;35:160-70

4. Ismail YH. Denture movement under occlusal forces [abstract 445]. J Dent Res 1971;50:164.

5. Kydd W, Stroud W, Moffett BC Jr, Tamarin A. The effect of mechanical stress on oral mucoperiosteum of dogs. Arch Oral Biol 1969;14:921-31
6. Lytle R. Soft tissue displacement beneath removable partial and complete dentures. J Prosthet Dent 1962;12:34-43.

7. Maeda Y, Okada M, Makishi A, Nokubi T, Okuno Y, Aoki T. Using mandibular kinesiograph for measuring complete denture movements - a preliminary report. J Osaka Univ Dent Sch 1984;24:123-9.

8. Picton D, Wills D. Viscoelastic properties of the periodontal ligament and mucous membrane. $J$ Prosthet Dent 1978;40:263-72

9. Sato Y, Tsuga K, Yoshida M, Kubo T. Factors influencing the clinical composite assessment of denture-supporting tissues. Int J Prosthodont 2002;15:49-54.

10. Wills DJ, Manderson RD. Biomechanical aspects of the support of partial dentures. J Dent 1977;5:310-8.

\section{Scientific Electronic Library Online

SciELO - Scientific Electronic Library Online é uma coleção eletrônica de revistas científicas disponíveis na Internet. A coleção traz os textos completos de artigos científicos, bases de dados e relatórios de uso e de impacto da literatura científica publicada no site.

Em operação desde 1997, atualmente estão disponíveis 29 revistas brasileiras nas áreas de ciências biológicas e da saúde, ciências sociais e humanas, ciências agrárias, física etc. Novas publicações são incluídas regularmente em várias especialidades.

Entre as revistas de nossa coleção, está a Pesquisa Odontológica Brasileira.

Consulte a Pesquisa Odontológica Brasileira (Revista de Odontologia da USP) na SciELO - http://wwww.scielo.br/rousp 